\title{
Skin tumours in Pleuronectes obscurus (Pleuronectidae) represent a complex combination of epidermal papilloma and rhabdomyosarcoma
}

\author{
I. G. Syasina ${ }^{1, *}$, A. S. Sokolovsky ${ }^{1}$, M. Phedorova ${ }^{2}$ \\ ${ }^{1}$ Institute of Marine Biology, Far East Branch, Academy of Sciences of Russia, Vladivostok 690041, Russia \\ ${ }^{2}$ Far East State University, 8 Suchanova Street, Vladivostok 690000, Russia
}

\begin{abstract}
In the present work we describe the histology of skin tumours of the black plaice Pleuronectes obscurus from Amursky Bay, the Sea of Japan. The epidermis forms numerous papillary folds protruding above the skin surface and supported by delicate branches of connective tissue. This type of neoplasm is classified as epidermal papilloma. The occurrence of severe epidermal hyperplasia and disturbance of the histoarchitecture in some areas, invasion of the adjacent connective tissues by epithelial cells, dystrophic changes of the epithelial cells, and the occurrence of a large number of mitoses point to an increasing malignancy of the papilloma. Moreover, areas with skeletal-muscle differentiation were found within skin tumours. Among the myogenic cells, features of normal somatic myogenesis were observed along with signs of abnormality of this process, suggesting a disturbance of myogenic differentiation. Cellular polymorphism among myogenic cells and invasion of the skin by neoplastic cells are evidence of the malignant character of this type of tumour and allow us to classify it as rhabdomyosarcoma. Due to the position of tumours in the skin, they are ectopic rhabdomyosarcomas. In the skin tumours, atypical small and large rounded cells were identified, the latter having previously been described in flatfish as X-cells. The origin of these cells is discussed and the assumption is put forward that small and large rounded cells can be regarded as cellular elements of rhabdomyosarcomas.
\end{abstract}

KEY WORDS: Skin tumours $\cdot$ Epidermal papilloma $\cdot$ Rhabdomyosarcoma $\cdot$ X-cell $\cdot$ Flatfish

\section{INTRODUCTION}

Until recently, no reports on tumour-bearing fish in Amursky Bay had been published. Tumours in the skin of Pleuronectes obscurus were first detected in 1995 and classified as epidermal papilloma (Syasina \& Sokolovsky 1997). Earlier, Fujimoto et al. (1986) described epidermal papillomas in the same species from coastal waters of Japan.

The structure of flatfish papillomas is extraordinarily complex (Peters et al. 1978). Peters \& Watermann (1979) distinguished 3 structurally different skin papillomas: flat 'fish-pox'-like tumours with a low connective tissue content, collagen-rich papillomas, and complex papillomas, which are characteristically composed of so-called X-cells with envelope cells between them.

•E-mail: inmarbio@mail.primorye.ru
In the third type of tumour, as it grows in size, an increasing number of rounded, voluminous $X$-cells displace malpighian cells in the epidermal portion (Brooks et al. 1969) and eventually become the dominant elements.

This paper describes the morphology of the skin tumours of Pleuronectes obscurus from Amursky Bay, Sea of Japan, which are classified as a complex combination of 2 types of heterogeneous tumours, epidermal papilloma and rhabdomyosarcoma.

\section{MATERIALS AND METHODS}

The black plaice Pleuronectes obscurus (Herzenstein) is widely distributed in the coastal waters of Peter the Great Bay. Fish were captured with a fry net from the shore from a depth of 0 to $1 \mathrm{~m}$ in Amursky Bay 
near Skrebtsov Island in the recreational zone of Vladivostok (Fig. 1) between May and October 1995. Our research was also resumed in May-October 1996 and additional fish were taken from a depth of 5 to $6 \mathrm{~m}$. A total of 600 individuals of $P$. obscurus were visually examined and tumours were found in 24 specimens (Table 1). All plaice with neoplasms on the skin were taken for histological analysis. Pieces of the skin together with underlying muscle tissue were excised, fixed with Bouin's fluid and embedded in paraffin. Sections 5 to $6 \mu \mathrm{m}$ thick were stained with haematoxylin and eosin (H\&E) and examined.

\section{RESULTS}

Tumours most frequently occurred in small specimens with a body length of $7.2 \mathrm{~cm}$ to $19 \mathrm{~cm}$ caught at a depth up to $1 \mathrm{~m}$ (Table 1). Only in 3 cases were lesions detected in individuals $\geq 20 \mathrm{~cm}$. The prevalence of tumours ranged from 0 to $12 \%$ (in May 1996) in the catch, and was $4 \%$ of the examined fish in the years 1995-1996.

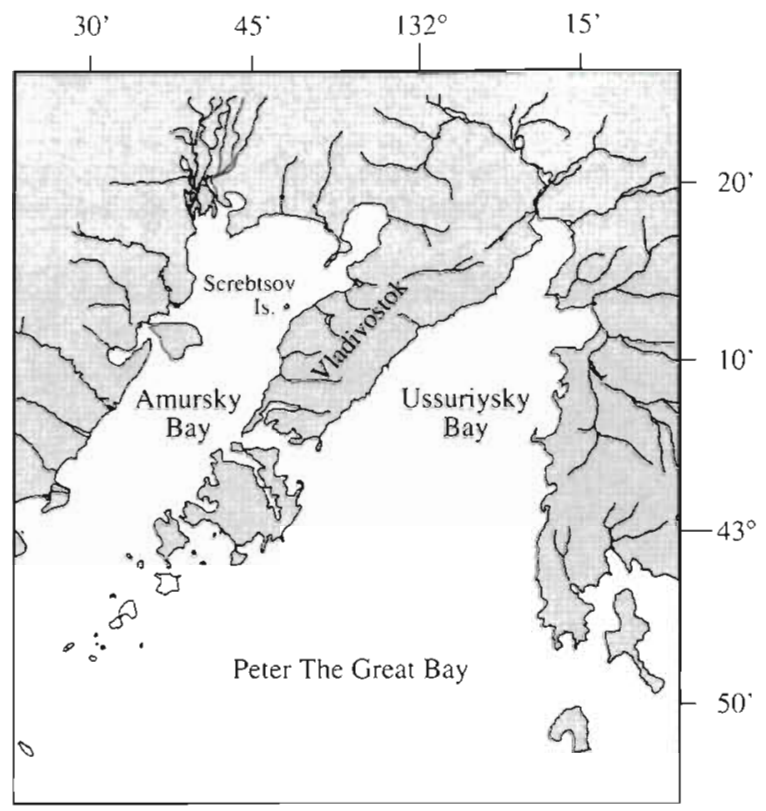

Fig. 1. Location of sampling station in Amursky Bay (Sea of Japan)

Table 1. Pleuronectes obscurus. Characteristics of skin tumours in the plaice

\begin{tabular}{|c|c|c|c|c|c|}
\hline $\begin{array}{l}\text { No. of fish } \\
\text { with tumours }\end{array}$ & $\begin{array}{l}\text { Date of } \\
\text { sampling }\end{array}$ & $\begin{array}{l}\text { Fish length } \\
\quad(\mathrm{cm})\end{array}$ & $\begin{array}{l}\text { Kind of } \\
\text { tumour }\end{array}$ & $\begin{array}{l}\text { Size } \\
(\mathrm{mm})\end{array}$ & $\begin{array}{l}\text { Macroscopic appearance } \\
\text { and position on body }\end{array}$ \\
\hline 1 & 17 May 1995 & 8 & Single & $5 \times 8 \times 1$ & $\begin{array}{l}\text { Insignificant thickening of the skin } \\
\text { on the dorsal surface }\end{array}$ \\
\hline $2^{b}$ & 17 May 1995 & 15 & Single & $20 \times 30 \times 2$ & Bilateral nodule on the caudal fin \\
\hline 3 & 22 May 1995 & 10 & Single & Height up to 2 & $\begin{array}{l}\text { Insignificant thickening of the } \\
\text { skin on the dorsal surface }\end{array}$ \\
\hline 4 & 29 May 1995 & 7.5 & Single & $7 \times 8 \times 2$ & Nodule at the base of the ventral fin \\
\hline 5 & 29 Мау 1995 & 8 & Single & $10 \times 8 \times 2$ & Nodule at the base of the pectoral fin \\
\hline 6 & 01 Jun 1995 & 14 & Multiple & Height up to 2 & $\begin{array}{l}\text { Bilateral nodules at the base of } \\
\text { dorsal fin and on dorsal surface }\end{array}$ \\
\hline 7 & 14 Jun 1995 & 10.5 & Single & Height up to 2 & $\begin{array}{l}\text { Insignificant thickening of the } \\
\text { skin on the dorsal surface }\end{array}$ \\
\hline $8^{\mathrm{h}}$ & 14 Jun 1995 & 13.5 & Single & Height up to 2 & Bilateral nodules at the base of the dorsal fin \\
\hline 9 & 22 Jun 1995 & 18 & Multiple & $\begin{array}{l}\text { Height up to } 5 ; \\
\text { area up to } 1 / 3 \text { of } \\
\text { the dorsal surface }\end{array}$ & $\begin{array}{l}\text { Bilateral nodule on the caudal fin and } \\
\text { multiple nodules on the dorsal surface, } \\
\text { hemorrhage }\end{array}$ \\
\hline 10 & 19 Jul 1995 & 10 & Single & $10 \times 10 \times 2$ & Bilateral nodule on the dorsal fin \\
\hline 11 & 14 Aug 1995 & 13 & Single & $5 \times 5 \times 2$ & $\begin{array}{l}\text { Insignificant thickening of the } \\
\text { skin on the dorsal surface }\end{array}$ \\
\hline 12 & 23 Aug 1995 & 13 & Single & $20 \times 20 \times 4$ & Nodule on the ventral fin \\
\hline $13-16$ & 05 May 1996 & $16 ; 20 ; 21 ; 23$ & Single & $\begin{array}{l}\text { Height up to } 2 \\
\text { area up to } 1 / 3 \text { of } \\
\text { the dorsal surface }\end{array}$ & $\begin{array}{l}\text { Insignificant thickening of the skin } \\
\text { on the dorsal surface with plenty of mucus }\end{array}$ \\
\hline 17 & 24 May 1996 & 1.7 & Single & Height up to 20 & $\begin{array}{l}\text { Massive pedunculated tumour in the } \\
\text { central part of the ventral surface }\end{array}$ \\
\hline 18 & 11 Jun 1996 & 11 & Single & $10 \times 12 \times 3$ & Nodule on the dorsal surface \\
\hline 19 & 11 Jun 1996 & 15 & Single & Height up to 20 & Massive pedunculated tumour on the head \\
\hline $20^{b}$ & 14 Jun 1996 & 19 & Multiple & Height up to $4-5$ & Nodules on the dorsal surface \\
\hline $21^{\mathrm{b}}$ & 05 Jul 1996 & 15 & Single & $30 \times 30 \times 4$ & Bilateral nodule at the base of the ventral fin \\
\hline 22 & 14 Aug 1996 & 11 & Single & Height up to $2-3$ & $\begin{array}{l}\text { Insignificant thickening of the skin } \\
\text { on the dorsal surface }\end{array}$ \\
\hline 23 & 21 Sep 1996 & 7.2 & Single & $5 \times 8 \times 2$ & Nodule on the caudal fin \\
\hline 24 & 07 Oct 1996 & 17 & Single & $15 \times 20 \times 3$ & Nodule on the dorsal surface, hemorrhage \\
\hline
\end{tabular}




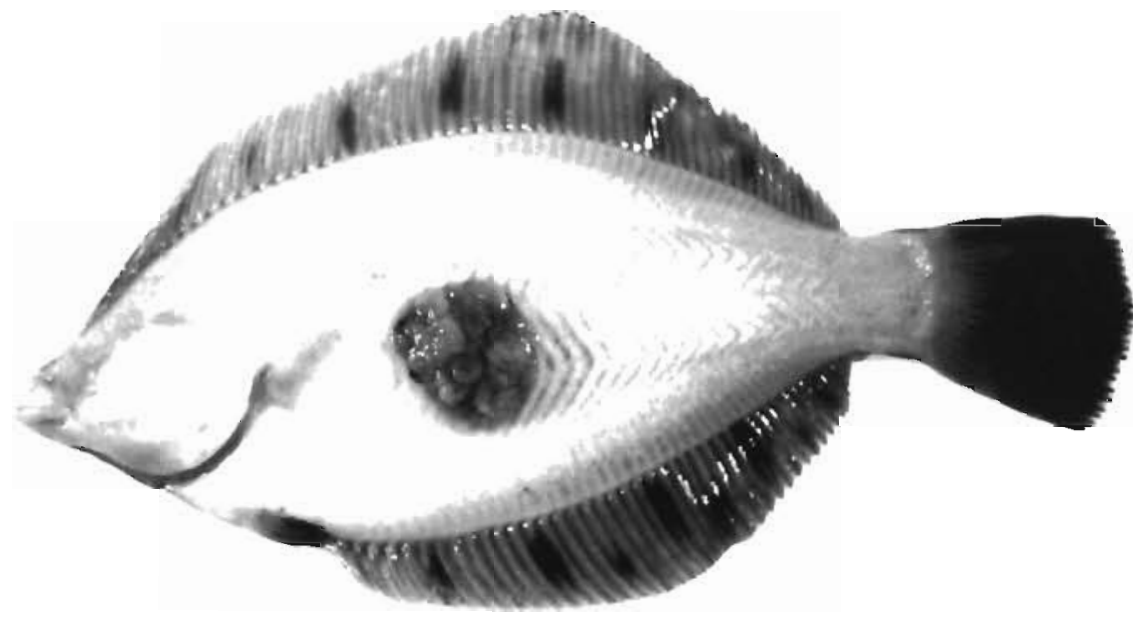

Fig. 2. Pleuronectes obscurus, size $=17 \mathrm{~cm}$, with a skin tumour located in the central part of the unpigmented body side

membrane. The epidermis retained the basic features of the normal structure although formation of papillomas was observed. Specialized cellular elements were present in the epidermis, and mucous cells occurred in large quantities. The epidermis was separated from the adjacent connective tissue by the basal membrane which was clearly visible. Under the basal membrane, there were numerous pigmented cells (melanocytes), varying in form from oval to star-shaped. The connective tissue of the stroma was moderately developed, with numerous blood vessels and lymphatic spaces. There

\section{Macroscopic appearance of tumours}

Tumours were located on the surface of the fish in every part of the body: on the ventral and dorsal surface, head and fins. On the dorsal surface, tumours occurred most often and sometimes were multiple. In the majority of cases, tumours were bilateral if located on the fins. In half of the cases, tumours consisted of an insignificant thickening of the skin with a coarsely nodular surface. This type of neoplasm could occupy up to $1 / 3$ of the dorsal and fin surfaces. The affected sites were covered by a thick layer of mucus. In 2 plaice with a body length of 15 and $17 \mathrm{~cm}$, we found massive pedunculated tumours, up to $20 \mathrm{~mm}$ in height. In one fish, the tumour was located on the head and extended over the eyes, and, in the other, in the central part of the unpigmented body side (Fig. 2). Otherwise, tumours consisted of nodules up to 4-5 $\mathrm{mm}$ high with a wide base extending from $3 \times$ $3 \mathrm{~mm}$ to $30 \times 30 \mathrm{~mm}$. Their colour varied from gray to light-brown on the ventral side of the fish and from dark-brown to black on the dorsal side. In 2 cases, the tumour surface was ulcerated and hemorrhages were observed.

\section{Microscopic structure}

Small and large tumours, but not more than 2 to $3 \mathrm{~mm}$ in height, consisted of numerous papillary folds of the epidermis, projecting from the surface and supported by branches of the connective tissue (Fig. 3). As in normal fish epidermis, 3 layers could be seen in the epidermal folds, the cells of which differed in size and in the orientation of the long axis relative to the basal was a large number of mitoses in different layers of the epidermis and endothelial cells of the capillaries.

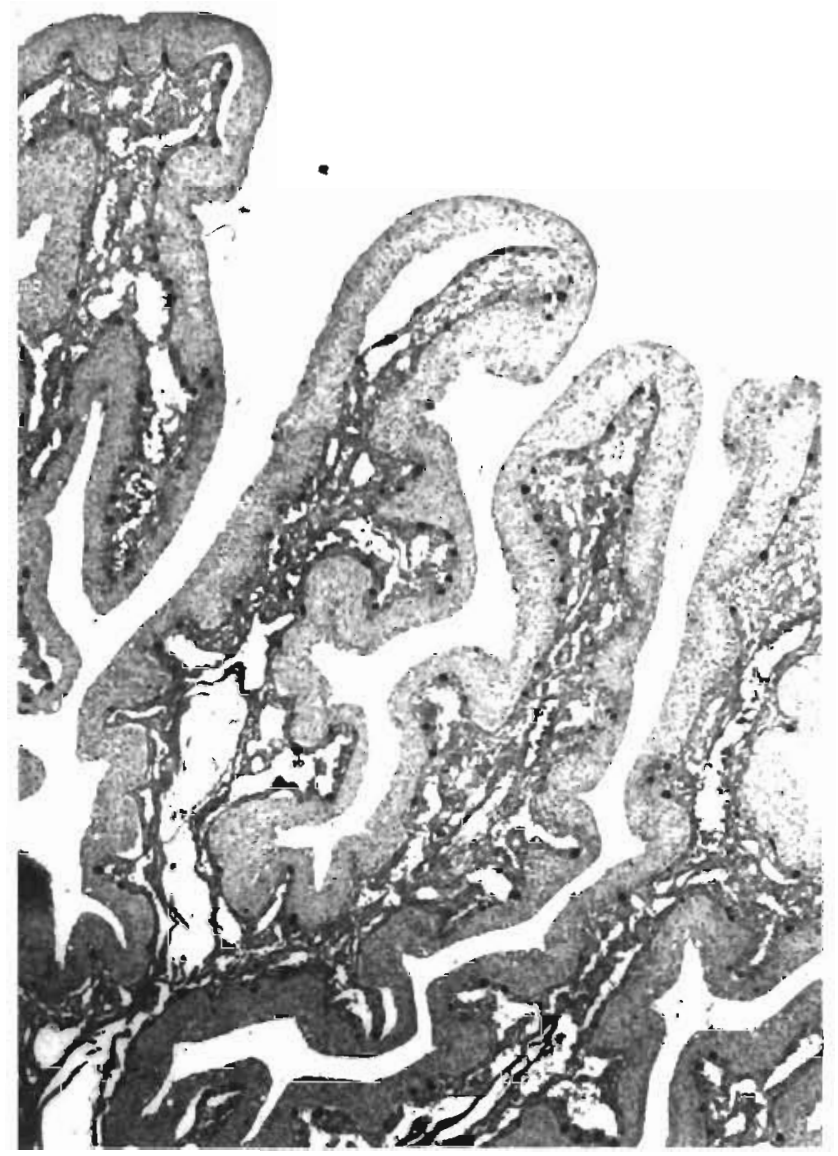

Fig. 3. Pleuronectes obscurus. Typical histomorphological structure of small skin tumours: epidermal papillary folds and supporting connective tissue. $\times 40$ 
Two forms of invasion of the adjacent connective tissues by epithelial cells were noted. In a number of cases, massive acanthotic epithelial strands had immersed into the adjacent connective tissues, forming isolated groups of epithelial cells. A basal membrane surrounded these groups of epithelial cells. Sometimes, local destruction of the basal membrane and penetration of a small number of the epithelial cells. mainly from the basal layer, into the connective tissue occurred.
In larger tumours, the papillary structure was destroyed, and generally these neoplasms were amorphous (Fig. 4). Areas with a papillary structure could be seen only on the periphery of such lesions. In some areas, the thickness of the epidermis increased considerably and, thus, the number of epithelial layers could not be determined. In the epidermis, cyst-like structures formed, in which cells underwent dystrophic changes (Fig. 4a). Histopathological changes in the connective tissue were also revealed: stagnant hyperemia, expansion of capillaries, hemorrhage (Fig. 4b), and necrotic changes in the central part of such tumours.

Thus, the presence of numerous papillary folds supported by delicate branches of the connective tissue allows us to classify this type of neoplasm as epidermal papilloma. Destruction of the basal membrane of the epidermis, invasion of the connective tissue by the epithelial cells, dysplastic and dystrophic changes in the epithelial cells, and the occurrence of mitoses suggest an increase in the malignancy of this type of neoplasm.

Special areas with skeletal-muscle differentiation were found in 4 out of 24 fishes with tumours (Table 1, Fig. 5). In the first case, the area consisted of a group of uninuclear cells, which appear to be myoblasts and small myosymplasts. These formations were observed at the edge of the tumour. Myoblasts were oval or spindle-shaped and formed long extensions directed towards each other (Fig. 6). Moderately condensed chromatin was present in the nuclei. In some myoblasts, mitoses at the stages of pro-, meta-, and anaphase were observed. Myoblast fusion led to formation of structures resembling different developmental stages of the myotube. Myoblasts had formed myosymplasts with the number of nuclei ranging from 7 to 15. Bundles of myofibrils with a distinct cross striation were only present in the cytoplasm of some myosymplasts (Fig. 7). The arrangement of bundles was either irregular or almost parallel.

In the second case, 2 small myosymplasts were also found at the external edge of the tumour. In the third case, areas of myogenic cells were seen in the base of the tumour in the dermal layer of
Fig. 4. Pleuronectes obscurus. Destruction of the papillary folds. (a) Increase in thickness of the epidermis in some areas; formation of cyst-like structures in the epidermis. (b) hyperemia and hemorrhagia in the connective tissue. $\times 97$ 

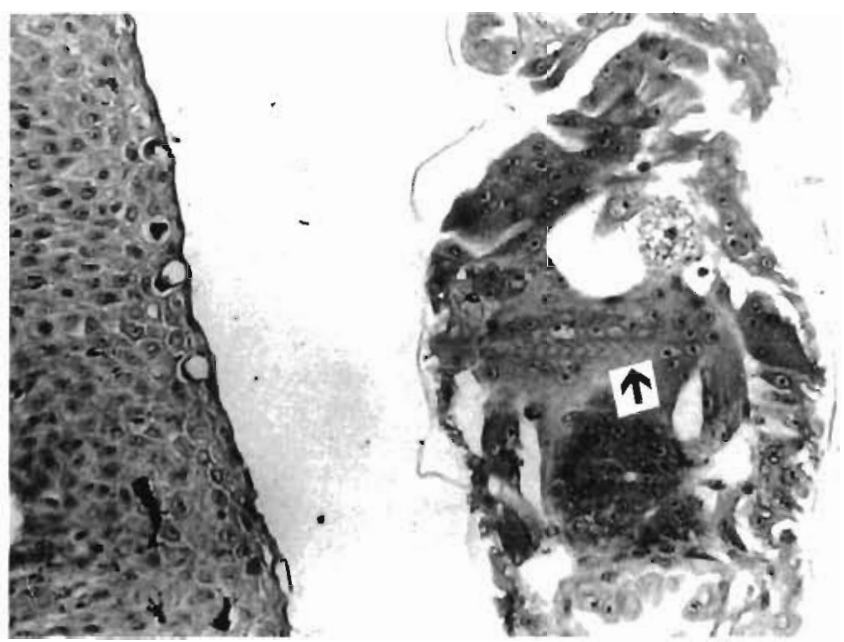

Fig. 5. Pleuronectes obscurus. Part of a skin tumour with skeletal-muscle differentiation (arrow). Transverse section of papilloma, $\times 220$

the skin near large rounded cells. In this case, most of the tumour consisted of large rounded cells. The areas with myogenic cells were composed of myosymplasts of different sizes (Fig. 8). The morphology of the symplasts differed from that described in the first case. Small myosymplasts with very small nuclei, small ones with larger nuclei, occupying the periphery of myosymplasts, and large ones with large nuclei arranged

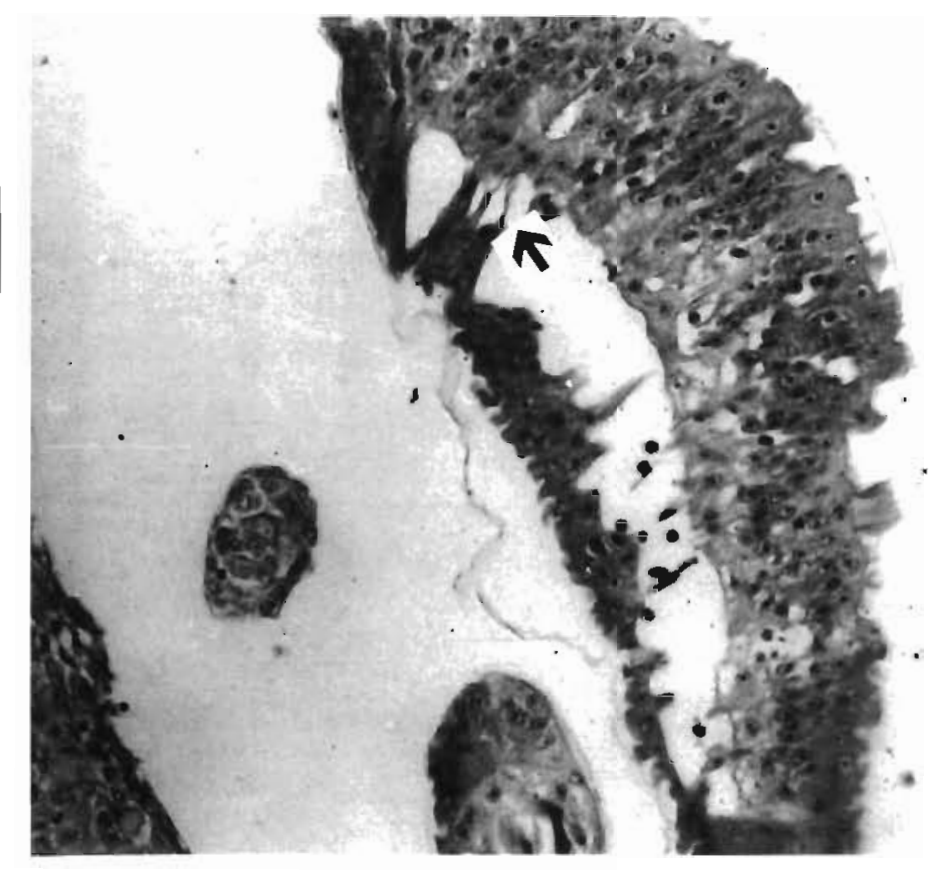

Fig. 6. Pleuronectes obscurus. Individual myoblasts in an area of tumour with skeletal-muscle differentiation. Myoblasts form long extensions, directed towards each other (arrow) $\times 250$

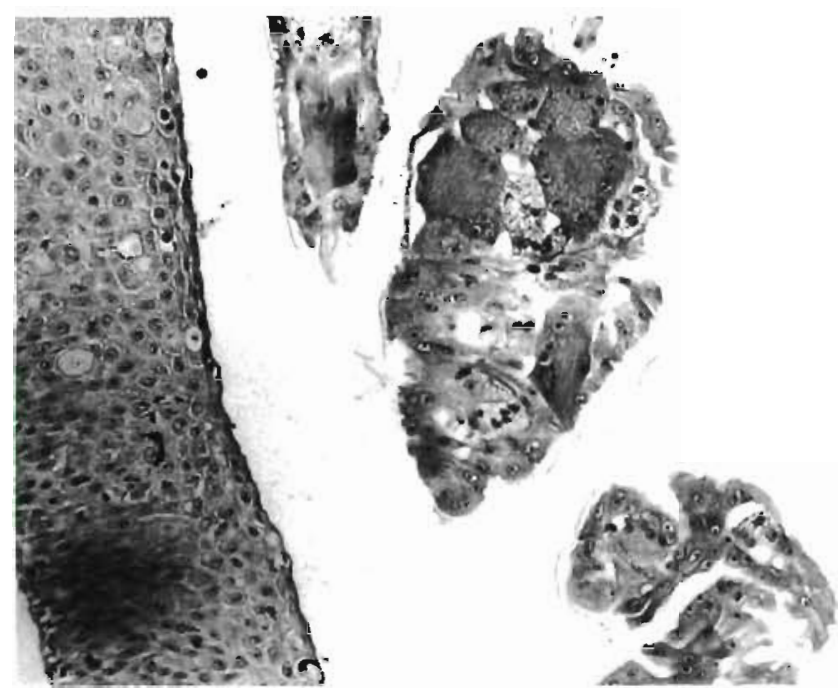

Fig. 7. Pleuronectes obscurus. Differentiation of myoblasts with formation of myosymplasts and bundles of myofibrils with distinct cross striation in the cytoplasm of the myosymplasts. $\times 150$

in 2 to 3 layers were distinguished. In nuclei of myosymplasts, large granules of condensed chromatin were easily discernible. Bundles of myofilaments with a transverse striation were irregularly scattered in the cytoplasm of most symplasts. A few large multinuclear cells were also found in this tumour, which were in close contact with large rounded cells. In the fourth case, strongly deformed individual myotubes were identified in the tumour stroma. Nuclei were elongated with uniformly stained chromatin.

An examination of serial slides revealed that, in all 4 tumours, the areas with myogenic cells were not

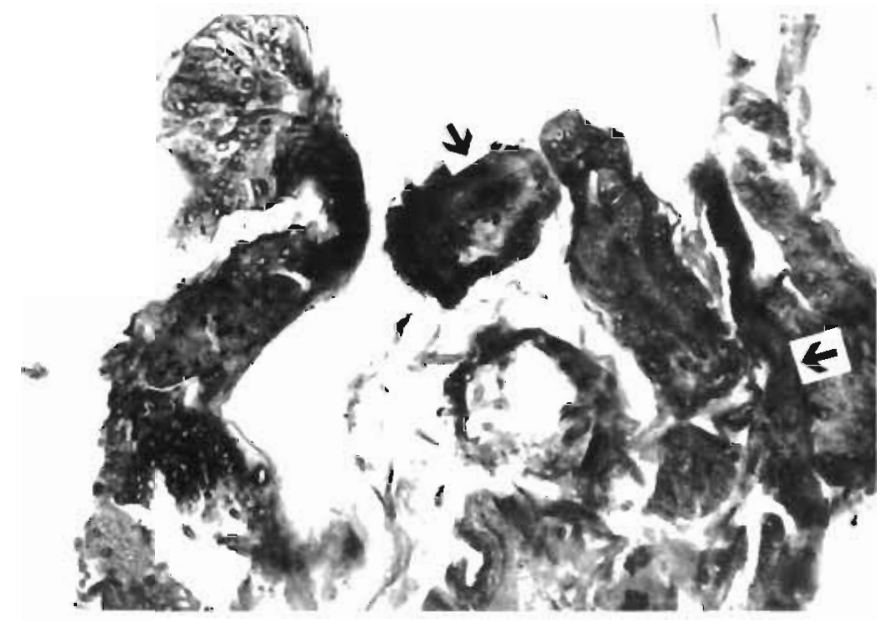

Fig. 8. Pleuronectes obscurus. Anomalous myosymplasts with nuclei of different sizes. Arrows point to myofilaments with cross striation. $\times 220$ 
structurally connected with striated muscle, but were located within neoplastic tissue. Cellular polymorphism among myogenic cells, abnormality of myogenic differentiation, and invasion of the dermal connective tissue by neoplastic cells are evidence of a malignant character and allow us to classify the tumours as rhabdomyosarcoma.

Within skin tumours, 2 other types of atypical cells were also identified: large rounded cells and small rounded cells. The small rounded cells measured 3 to $5 \mu \mathrm{m}$ and had oval nuclei with a distinct nucleolus and very little cytoplasm, which stained pink with eosin. The small rounded cells frequently occurred in groups located chiefly along the blood vessels and capillaries in the connective tissue supporting the papillomas (Fig. 9). The number of small rounded cells was greater at the base of tumours. Large rounded cells were larger (up to $20-60 \mu \mathrm{m}$ ) than the normal epidermal cells $(5-12 \mu \mathrm{m})$. Nuclei were rounded or irregular in shape with a large nucleolus. The cytoplasm of these cells was grainy. In some large rounded cells, large vacuoles were present in the cytoplasm. Some of these cells were degenerating. Large rounded cells replaced the epidermal cells (Fig. 10). Such cells are known as X-cells.

The histological structure of tumours displayed considerable variation depending on the prevalence of 1 type of atypic cell or the joint occurrence of several types. In the first variant, the basic part of the tumours was formed by epidermal papillomas. In the supporting connective tissue, there was a varying number of small rounded cells. In the second variant of tumours, the basic part was composed of large rounded cells which replaced epidermal cells. Papillary folds of the epidermis did not occur frequently. There were small rounded cells in the connective tissue and between the large rounded cells.

\section{DISCUSSION}

The occurrence of skin tumours has been recorded in a large variety of fish species (Peters 1984). In most cases, skin tumours were classified as epidermal papillomas. X-cell papillomas have been identified in flat fish species from different locations: in sand sole Psettichthys melanostictus from northern Hecate Strait, British Columbia, Canada (Nigrelli et al. 1965), English sole Parophrys vetulus and starry flounder Platichthys stellatus from Puget Sound, Washington, USA (MCArn et al. 1968, Angell et al. 1975, Wellings et al. 1976), English sole from the coastal areas near Vancouver, Canada (Stich et al. 1977), rock sole Lepidopsetta bilineata from the Bering Sea (McCain et al. 1978, 1979). Reports on detection of X-cell lesions in the pseudobranches (Watermann \& Dethlefsen 1982), gills (McVicar et al. 1987. Franklin \& Davison 1988), and liver (Dykova et al. 1993) have appeared lately.

The origin of X-cells is still unknown. Some researchers believe $X$-cells to be parasitic amebas, possibly belonging to the order of Hartmanellidae, which,

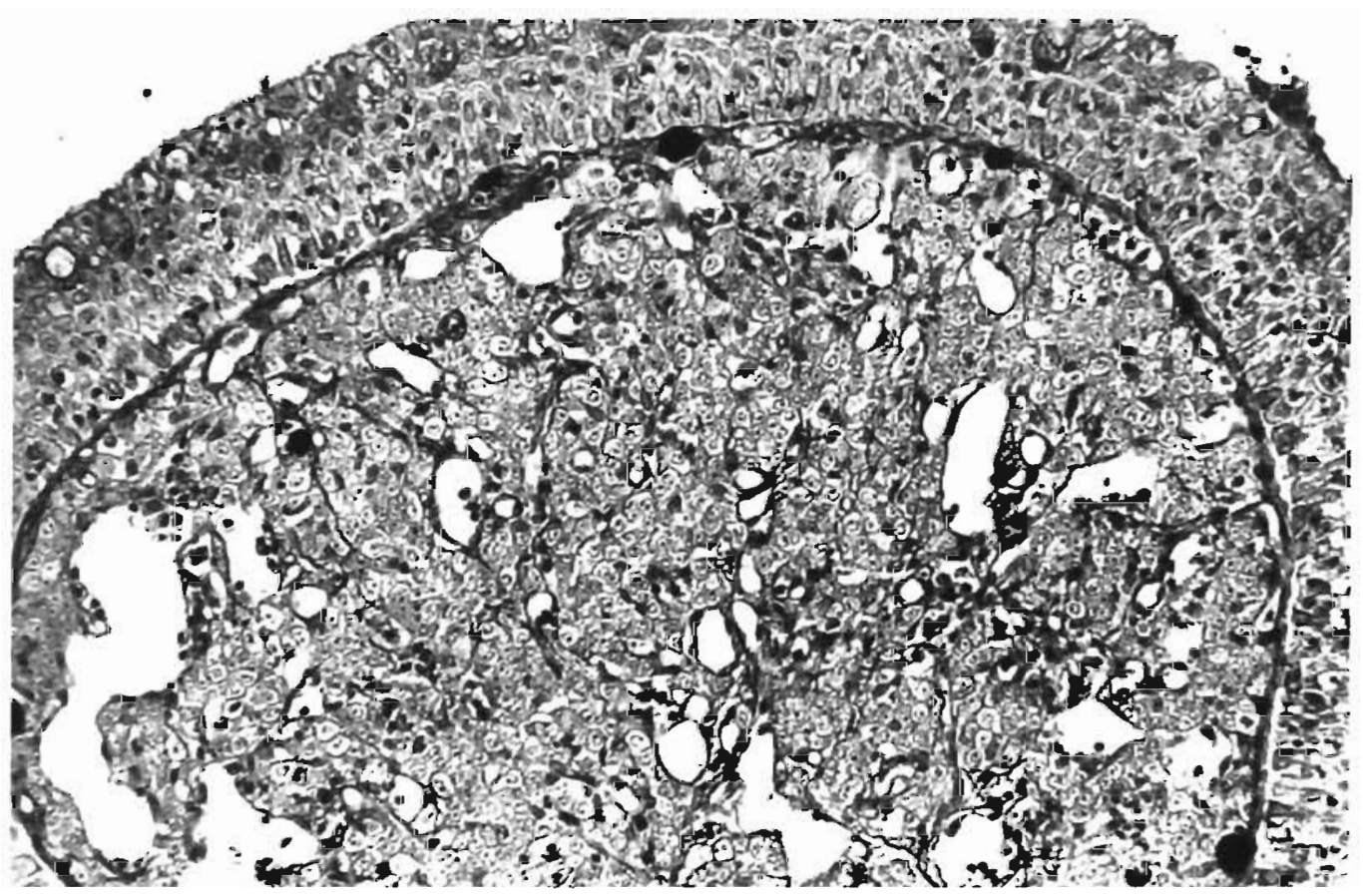

Fig. 9. Pleuronectes obscurus. Small rounded cells in the supporting connective tissue of the skin tumours. $\times 400$ 


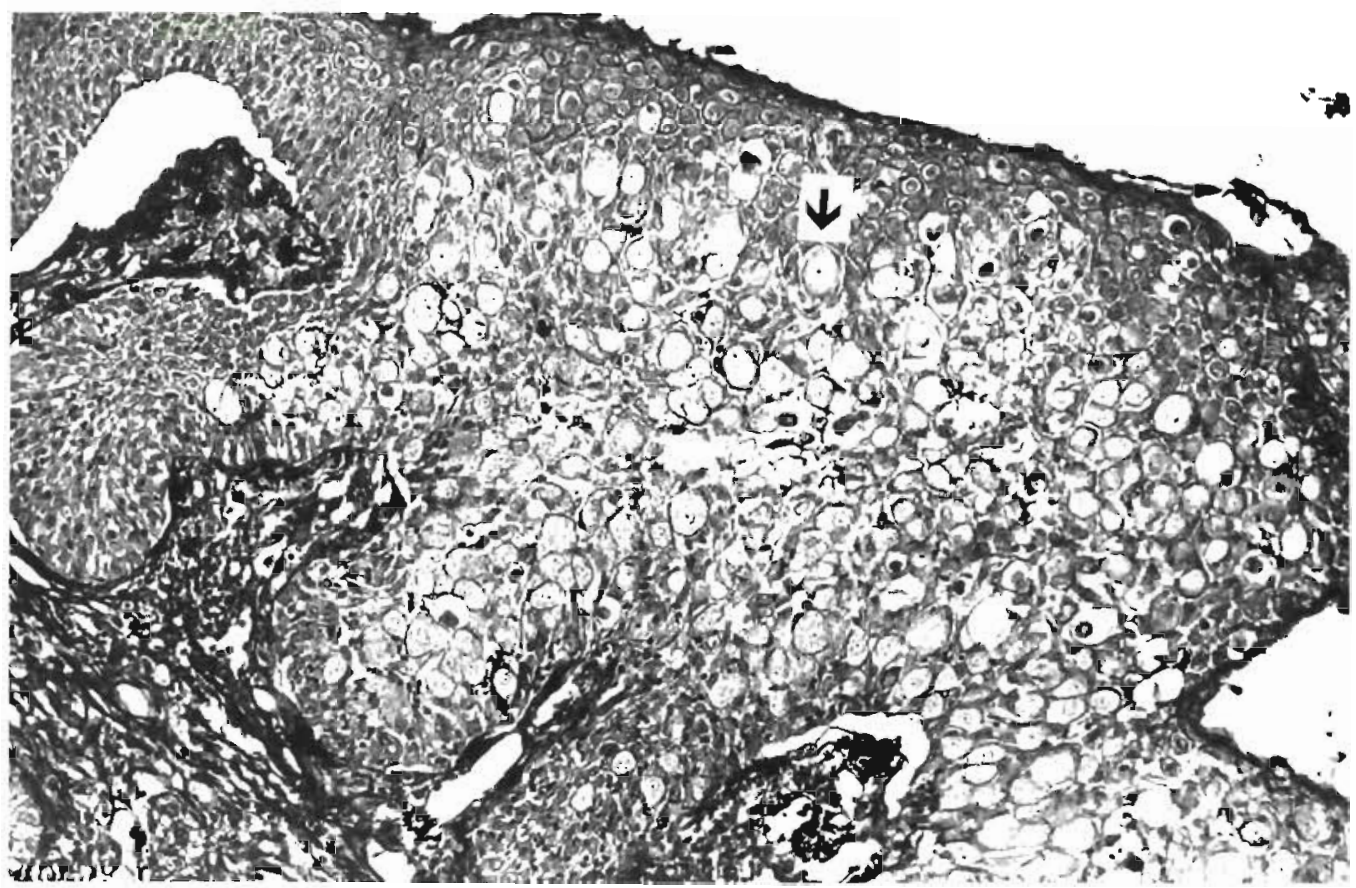

Fig. 10. Pleuronectes obscurus. Large rounded cells replace epidermal cells (arrow). $\times 100$

together with host tissue, form aggregates in the skin or pseudobranches (Dawe 1981, Watermann \& Dethlefsen 1982). Accordingly X-cell tumours are classified as pseudotumours (Harshbarger 1984). A recent attempt to prove the protistan nature of the X-cells in cod by means of the application of metronidazole, which acts especially on protozoan organisms, was unsuccessful (Watermann et al. 1994). Other workers believe that $\mathrm{X}$-cells are fish cells transformed by such agents as viruses (Wellings et al. 1977, Peters et al. 1978, 1981 Yamazaki et al. 1978, Bloch et al. 1986). The role of viruses in the induction of skin tumours and tumourlike proliferations of fish was reviewed by Anders \& Yoshimizu (1994). The morphology of X-cells has been studied by electron microscopy (Brooks et al. 1969 Peters et al. 1981), but the genesis of these cells has not been determined. It has not yet been established whether X-cells reproduce by mitosis or in another mode. Their nuclei could not be labeled with ${ }^{3} \mathrm{H}$ thymidine (Kranz et al. 1980).

Skin tumours have also been recorded in black plaice Pleuronectes obscurus off the shore of Peter the Great Bay (Syasina \& Sokolovsky 1997). While these tumours have previously been classified as epidermal papilloma, the results of the present study indicate that other tumour types may be involved as well. The finding of areas with signs of skeletal-muscle differentiation, including the presence of atypical multinuclear myosymplasts of different sizes with the nuclei orga- nized in 2 or 3 layers and the different direction of myofilament bundles in symplasts indicate that these tumours are rhabdomyosarcomas. The observed pictures of myoblast division and formation of myosymplasts cannot be attributed to normal reparative or pathological regeneration, since these cells are not structurally connected with muscle tissue. A chaotic disposition of myotubes and myofibrils in myosymplasts was previosly described in a skeletal muscle tumour of mammals (Nameroff 1970). Muscle tissue tumours are seldom encountered in fishes (Harshbarger 1965-81, Peters 1984). We failed to find any data on ectopic rhabdomyosarcomas of flatfish or other species of fish in the available literature.

Although rhabdomyosarcoma were only identified in 4 out of 24 fish affected by epidermal papilloma, the presence of atypical small and large rounded cells in all papilloma can be regarded as an indication that the tumours are of a more complex nature than previously expected. Small and large rounded cells resembling those found in the papilloma of black plaice have been described before in tumour studies in mammals (Vakhtin 1981) to be cellular elements of rhabdomyosarcoma. Therefore, the possibility cannot be excluded that the skin tumours of black plaice represent a combination of epidermal papilloma and rhabdomyosarcoma.

The finding that clear cases of rhabdomyosarcoma did not occur in all fish with tumours might be due to 
the fact that this type of a tumour has a varying cellular composition and not all cells show attributes of muscle differentiation. Spontaneous rhabdomyosarcomas of humans and animals and experimental rhabdomyosarcomas of mice are sometimes unrelated to muscle tissue and characterized by polymorphism of cellular elements and a significant degree of cataplasia (Willis 1967, Minkus \& Hillemanns 1997), which makes their differential diagnosis difficult. In light and electron microscope studies of rhabdomyosarcomas, 3 to 4 basic types of cellular elements have usually been described (Vakhtin 1981). Use of a clonal analysis has made it possible to reveal about 10 types of hereditarily different cellular elements of rhabdomyosarcomas, such as large, medium and small spindle-shaped cells, large and small rounded cells, large and small pleomorphic cells and mesenchyme-like cells (Vakhtin 1981). Homogenic myogenic sarcomas composed of 1 type of tumorous cell and myogenic mesenchymal tumours occurred very seldom. Depending on the capacity for cytotypical and histotypical differentiation, all types of cellular elements of mammal rhabdomyosarcomas are divided into differentiating elements (large and average spindle cells, large round cells) and undifferentiating elements (all others) (Vakhtin 1981)

Complex tumours in fish are rare. Lighther (1974) reported an ossifying fibroma in the head of a striped mullet Mugil cephalus caught in the Gulf of Mexico. An osteochondroma was documented in the left operculum of a gilthead sea bream Sparus aurata experimentally cultured in the Gulf of Aqaba (Nash \& Porter 1985). Another kind of multiple tumour, osteofibrosarcoma, of a crimson sea bream Evynnis japonica was described by Honma (1988). In the pike Esox lucius from the Baltic Sea, a combination of epidermal hyperplasia with lymphosarcoma, affecting connective tissue of the derma was described (Ljunberg 1976). In mammals, verrucous epidermal changes and papillomatosis may be seen in a wide variety of skin diseases and also can develop at formation of malignant sarcomas, in particular, angiosarcomas in underlying dermis (Diazcascajo et al. 1998).

The tumours observed show signs of malignancy: invasion of neoplastic cells into the skin and necrotic changes in the central part of tumours. This might explain the fact that tumours were more prevalent in small fish as compared to large fish, possibly due to mortality. This agrees with the data on the occurrence of X-cell tumours in small fish in other areas (Wellings et al. 1964). Mortality in fish with X-cell disease has previously been described in starry flounder Platichthys stellatus with skin tumours (Campana 1982) and in common dab Limanda limanda with X-cell gill disease (Diamand \& McVicar 1987, Mellergaard \& Nielsen 1996).
So far, there is no information available on the etiology of the skin tumours. However, a possible link with marine pollution has been discussed repeatedly (Vethaak \& ap Rheinallt 1992). The coastal waters of Peter the Great Bay near Vladivostok are contaminated by various toxicants, such as oil hydrocarbons, pesticides, and heavy metals (Khristoforova et al. 1993). The pollution level of coastal waters has decreased in the past few years, but the spectrum of pollutants remains wide. Probably, some of them act as tumour promotors. Research into the etiology of these lesions will be continued

Acknowledgements. We thank Dr V. Isaeva for fruitful discussions and for reading the manuscript and anonymous reviewers for helpful remarks and correcting the English language.

\section{LITERATURE CITED}

Anders K, Yoshimizu M (1994) Role of viruses in the induction of skin tumours and tumour-like proliferations of fish. Dis Aquat Org 19:215-232

Angell CL, Miller BS, Wellings SR (1975) Epizoology of tumours in a population of juvenile English sole (Parophrys vetulus) from Puget Sound, Washington. J Fish Res Board Can 32:1723-1732

Bloch B, Mellergaard S, Nielsen E (1986) Adenovirus-like particles associated with epithelial hyperplasias in dab, Limanda limanda (L.). J Fish Dis 9:281-285

Brooks RE, McArn GE, Wellings SR (1969) Ultrastructural observations on an unidentified cell type found in epidermal tumours of flounders. $J$ Natl Cancer Inst 43:97-109

Campana SE (1982) Mortality of starry flounder (Platichthys stellatus) with skin tumors. Can J Fish Aquat Sci 40: $200-207$

Dawe CJ (1981) Polyoma tumors in mice and X-cell tumors in fish viewed through telescope and microscope. In: Dawe CJ, Hershbarger JC, Kondo S, Sugimura T, Takayama S (eds) Phyletic approaches to cancer. Japan Sci Soc Press Tokyo, p 19

Diamant A, McVicar AH (1987) The effects of internal and external X-cell lesions on common dab, Limanda Limanda L. Aquaculture 67:127-133

Diazcascajo C, Weyers W, Borghi S, Reichel M (1998) Verrucous angiosarcoma of the skin: a distinct variant of cutaneous angiosarcoma. Histopathology 32(6):556-561

Dykova I, Figueras A, Novoa B (1993) X-cell lesions in the liver of coho salmon Oncorhynchus kisutch. Dis Aquat Org 15:171-174

Franklin CE, Davison W (1988) X-cells in the gills of an Antarctic teleost, Pagothenia borchgrevinki. J Fish Biol 32: $341-353$

Fujimoto $Y$, Madarame $H$, Yoshida $H$, Moriguchi R, Kodama $\mathrm{H}$, Iisawa H (1986) Pathological observations on epidermal papilloma of flatfish (Liopsetta obscura). Jpn J Vet Res 34 . $81-103$

Harshbarger JC (1965-81) Activities report. Registry of tumors in lower animals. National Museum of Natural History, Smithsonian Institution, Washington, DC

Harshbarger JC (1984) Pseudoneoplasms in ectothermic animals. Natl Cancer Inst Monogr 65:251-273 
Honma Y (1988) Droplets from the Sado Marine Biological Station, Niigata University-II. Two specimens of tumor bearing fishes. Rep Sado Mar Biol Stn, Niigata Univ N18 $1-11$

Khristoforova NK, Shul'kin VM, Kavun, VYa, Chernova EN (1993) Heavy metals in fished and cultivated species of marine mollusks in Peter the Great Bay. Publishing House, Dal'nauka, Vladivostok (in Russian)

Kranz H, Peters N, Bresching G, Stich HF (1980) On cell kinetics in skin tumours of the Pacific English sole, Parophrys vetulus Girard. J Fish Dis 3:125-132

Lightner DV (1974) Case reports of ossifying fibromata in the striped mullet. J Wildl Dis 10:317-320

Ljunberg O (1976) Epizootiological and Experimental Studies of skin tumours in Northern Pike (Esox lucius L.) in the Baltic Sea. Prog Exp Tumor Res 20:156-165

McArn GE, Chuinard RG, Miller BS, Brooks RE, Wellings SR (1968) Pathology of skin tumors found on English sole and starry flounder from Puget Sound, Washington. J Natl Cancer Inst 41:229-242

McCain BB, Myers MS, Gronlund WD, Wellings SR, Alpers CE (1978) The frequency, distribution, and pathology of three diseases of demersal fishes in the Bering Sea. $J$ Fish Biol 12:267-276

McCain BB, Gronlund WD, Myers MS, Wellings SR (1979) Tumors and microbial diseases of marine fishes in Alaskan waters. J Fish Dis 2:111-130

McVicar AH, Bucke D, Watermann B, Dethlefsen V (1987) Gill x-cell lesions of dab Limanda limanda in the North Sea. Dis Aquat Org 2:197-204

Mellergaard S, Nielsen E (1996) Epidemiology of X-cell gill disease in common dab Limanda limanda. Dis Aquat Org 25:107-116

Minkus G, Hillemanns M (1997) Botryoid-type embryonal rhabdomyosarcoma of liver in a young cat. Vet Pathol 34:618-621

Nameroff $M$ (1970) Myogenesis in a skeletal muscle tumor. Proc Int Conf Inst Muscle Disease, New York, p 231-241

Nash G, Porter C (1985) Branchial osteochondroma in a gilt head sea bream, Sparus aurata L., cultured in the Gulf of Aqaba. J Fish Dis 8:333-336

Nigrelli RF, Ketchen KS, Ruggieri GD (1965) Studies on virus diseases of fishes. Epizootiology of epithelial tumors in the skin of flatfishes of the Pacific Coast, with species reference to the sand sole (Psettichthys melanostictus) from northern Hecate Strait, British Columbia, Canada. Zoologica 50:115-122

Peters N (1984) Diseases caused by neoplasia. In: Kinne O

Editorial responsibility: Nicolaus Peters,

Hamburg, Germany (ed) Diseases of marine animals, Vol IV. Biologische Anstalt Helgoland, Hamburg, p 400-423

Peters N, Watermann B (1979) Three types of skin papillomas of flatfishes and their causes. Mar Ecol Prog Ser 1:269-276

Peters N, Peters G, Stich HF, Acton AB, Bresching G (1978) On differences in skin tumours of Pacific and Atlantic flatfishes. J Fish Dis 1:3-25

Peters N, Stich HF, Kranz H (1981) The relationship between lymphocystis disease and $\mathrm{X}$-cell papillomatose in flatfish. In: Dawe CJ, Hershbarger JC, Kondo $S$, Sugimura $T$, Takayama S (eds) Phyletic approaches to cancer. Japan Sci Soc Press, Tokyo, p 111-121

Stich HF, Acton AB, Oishi K, Yamazaki F, Harada T, Hibino T, Moser HG (1977) Systematic collaborative studies on neoplasms in marine animals as related to the environment. Ann NY Acad Sci 298:374-388

Syasina IG, Sokolovsky AS (1997) Skin tumors in the black plaice Pleuronectes obscurus from Amursky Bay, Sea of Japan. Russ J Mar Biol 23:160-163

Vakhtin JuB (ed) (1981) Genetic classification of rhabdomyosarcomas. An electron microscopic atlas. Nauka, Leningrad (in Russian)

Vethaak AD, ap Rheinallt T (1992) Fish disease as a monitor for marine pollution: the case of the North Sea. Rev Fish Biol Fish 2:1-32

Watermann B, Dethlefsen V (1982) Histology of pseudobranchial tumours in Atlantic cod (Gadus morhua) from the North Sea and the Baltic Sea. Helgol Meeresunters 35:231-242

Watermann B, Egidius E, Peters N, Schmidt W (1994) Occurrence and structure of cysts in X-cell lesions of Atlantic cod (Gadus morhua L.). ICES-CM 1994/E:12

Wellings SR, Cuinard RG, Gourley RT, Cooper RA (1964) Epidermal papillomas in the flathead sole, Hippoglossoides ellassodon, with notes on the occurrence of similar neoplasms in other pleuronectids. J Natl Cancer Inst 33: 991-1004

Wellings SR, McCain BB, Miller BS (1976) Epidermal papillomas in Pleuronectidae of Puget Sound, Washington. Prog Exp Tumour Res 20:55-74

Wellings SR, Alpers CE, McCain BB, Myers MS (1977) Fish disease in the Bering Sea. Ann NY Acad Sci 298:290-304

Willis RA (1967) Pathology of tumours. Butterworths, New York

Yamazaki F, Hibino T, Dishi K, Harada T, Stich HF, Acton AB (1978) X-cell morphology in epidermal papillomas of flatfish collected from coastal waters of Hokkaido, Japan. Bull Jpn Soc Sci Fish 44:407-413

Submitted: August 27, 1998; Accepted: June 28, 1999

Proofs received from author(s): December 9, 1999 